\title{
DAMPAK LINGKUNGAN DAN RISIKO BENCANA PENGEMBANGAN DESA WISATA STUDI KASUS DI DESA WISATA SAMBI
}

\author{
Sudarmadji dan Darmakusuma Darmanto \\ Fakultas Geografi Universitas Gadjah Mada \\ Email: sudarmadji@ugm.ac.id
}

\begin{abstract}
Merapivolcano has a lot of tourism potential objects. Local people's traditions and the local panorama caused many tourism villages to develope. Development of the tourismvillages in volcanic areas have positive and negative impactsto the environment including to the local community. It also has some disaster risks. This research was conducted at the Sambi Tourism Village located in the Southern Slope of Merapi Volcano, to study the environmental impacts and disaster risks. The study was conducted by collecting primary and secondary data. Primary data collected by field observations and interviews with local people and tourists. Data analyses was done by descriptive method. The results showed that the Sambi Tourism Village has good tourism potential to be developed. Tourism development has some positive impacts on economy of the local community, though there are some conflicts of interest among stakeholder. Negative impacts also occur, such as social tension and the degradation of local culture, especially "gotong royong".Sambi Tourism Village has some risk disaster due to Merapi Volcano activities, such as lahar floods and hot clouds.Environmental impacts and disaster risks should be considered in the further development of Sambi Tourism Village.
\end{abstract}

Keywords: Tourism Village, Development, Environmental Impact, Risk of Disaster.

\begin{abstract}
ABSTRAK
Gunungapi Merapi mempunyai potensi obyek wisata. Tradisi masyarakat setempat dan panorama setempat mendorong banyak dikembangkan Desa Wisata. Pengembangan Desa Wisata di daerah gunungapi mempunyai dampak positif dan dampak negatif terhadap lingkungan termasuk terhadap masyarakat setempat. Pengembangan ini juga menghadi risiko bencana. Penelitian ini dilakukan di Desa Wisata Sambi yang terletak di Lereng Selatan Gunungapi Merapi, untuk mempelajari dampak lingkungan dan risiko bencana yang dihadapi. Penelitian dilakukan dengan mengumpulkan data primer dan data sekunder. Data primer diperoleh dengan observasi lapangan dan wawancara dengan masyarakat setempat maupun wisatawan. Analisis data dilakukan dengan cara deskriptif kualitatif. Hasil penelitian menunjukkan bahwa Desa Wisata Sambi mempunyai potensi wisata untuk dikembangkan. Pengembangan wisata yang sudah dilakukan memberikan dampak positif bagi perekonomian masyarakat setempat, walaupun terkadang terjadi ketidak harmonisan antar pelaku kepentingan. Dampak negatif juga terjadi, yaitu terjadinya kecemburuan sosial dan pengikisan terhadap budaya setempat, terutama gotongroyong. Terdapat risiko bencana yang dihadapi akibat aktivitas Gunungapi Merapi, berupa banjir lahar dan kemungkinan awan panas. Dampak lingkungan dan risiko bencana perlu diperhatikan dalam pengembangan Desa Wisata Sambi.
\end{abstract}

Kata Kunci: Desa Wisata, Pengembangan, Dampak Lingkungan, Risiko Bencana. 


\section{PENGANTAR}

Gunungapi Merapi kaya akan obyek wisata alam yang berupa keindahan alam, tanah yang subur dan sumber air yang melimpah. Kehidupan masyarakat yang menyatu dengan alam merupakan sesuatu yang menarik, lebih-lebih terkaitdengan kearifan lokalnya dalam menjaga kelestarian alam. Budaya masyarakat dalam mengelola sumberdaya alam dan lingkungan yang harmonis menarik bagi orang dari luar daerah, lebih-lebih wisatawan mancanegara yang budayanya berbeda dengan masyarakat setempat. Banyaknya wisatawan yang ingin menikmati suasana lingkungan yang indah dan mempelajari budaya masyarakat setempat mendorong untuk dikembangkan desawisata yang berbasis kepada obyek wisata alam, sehingga banyak desa wisata yang dikembangkan di daerah Lereng Gunungapi Merapi. Salah satu di antara desa wisata tersebut adalah Desa Wisata Sambi yang terletak di wilayah Kecamatan Pakem.

Desa wisata dikembangkan sesuai dengan potensi yang dimiliki mempunyai prospek untuk meningkatkan kesejahteraan masyarakat, tetapi di sisi lain, pengembangan desa wisata mempunyai dampak negatif terhadap lingkungan hidup. Masuknya wisatawan dari luar daerah, lebih-lebih wisatawan mancanegara dapat mempengaruhi budaya masyarakat setempat. Hal ini perlu diwaspadai, agar budaya masyarakat setempat yang sudah kental dengan kearifan lokalnya masih dapat dipertahankan.

Pembangunan sarana pendukung sebagai desa wisata juga dapat menimbulkan dampak lingkungan terutama lingkungan fisik. Pembuatan jalan akses masuk, pembuatan rumah makan, dibukanya usaha-usaha lain dapat memberikan hasil sampingan yaitu limbah dan sampah yang dapat menimbulkan pencemaran lingkungan.

Daerah kaki gunungapi berfungsi sebagai daerah resapan air. Banyak mata air yang bermunculan di lereng gunungapi dari lereng curam ke lereng yang lebih landai. Mata air ini dapat muncul ke permukaan karena ada perubahan slope (Sudarmadji dkk. 2012). Kegiatan pariwisata memerlukan air untuk berbagai keperluan. Di sisi lain daerah lereng gunungapi pada umumnya mempunyai risiko bencana yang ditimbulkan oleh aktivitas gunungapi tersebut. Gunungapi Merapi yang sering mengalami erupsi dapat menimbulkan risiko bencana terhadap aktivitas pariwisata. Erupsi Gunungapi Merapi tahun 2010 merupakan bukti bahwa daerah wisata yang terletak di lereng Gunungapi Merapi menjadi korban dari aktivitas gunungapi. Oleh karena itu, selain dampak positif dan dampak negatif dari pengembangan desa wisata, risiko bencana perlu dikaji dalam pegembangan desa wisata selanjutnya.

Berdasarkan latar belakang yang sudah tersebut, maka penelitian ini bertujuan untuk (1) Mempelajari potensi desa wisata Sambi untuk mendukung pengembangan desa wisata. (2) Menganalisis manfaat yang diperoleh dari Desa Wisata Sambi yang berasal dari pariwisata. (3) Menganalisis dampak lingkungan dan risiko bencana yang dihadapi yang berpengaruh terhadap pengembangan Desa Wisata Sambi.

Pariwisata sebagai suatu bagian aktivitas manusia didefinisikan dalam berbagai sudut pandang oleh banyak ahli pariwisata dunia. Pendapat Leiper yang dikutip oleh Gartner (1996) menyebutkan bahwa pengertian pariwisata tidak hanya mencakup tentang aspek leisure, tetapi pariwisata merupakan sistem yang terbuka dari lima elemen yang berinteraksi dengan alam yang lebih luas, elemen manusia, wisatawan, dan tiga elemen geografi meliputi: wilayah yang melakukan kegiatan (generating region), rute yang dilalui (transit route), wilayah yang dituju (destination region), dan satu elemen ekonomi adalah industri ekonomi. Kesemuanya itu diatur dalam fungsi-fungsi yang berbeda-beda berinteraksi secara fisik, teknologi, sosial, budaya, ekonomi, dan faktor politik. Elemen yang dinamis terdiri dari orang-orang yang melakukan perjalanan, agak panjang yang didasari atas pikiran bersenang-senang, yang keterlibatannya dalam perjalanan 
meninggalkan rumah secara temporer paling sedikit satu malam. Dari pengertian tersebut memberikan penegasan bahwa pemahaman terhadap pariwisata tidak hanya terbatas kepada aktivitas manusianya, tetapi mencakup berbagai elemen lainnya.

Pendit (1999) menyebutkan bahwa potensi wisata adalah segala sesuatu yang dapat dikembangkan menjadi daya tarik wisata, dapat dibagi menjadi dua, yaitu (1) Potensi Budaya, merupakan potensi yang tumbuh dan berkembang di masyarakat, seperti adat-istiadat, mata pencarian, kesenian dan budaya; (2) Potensi alamiah, merupakan potensi yang ada di masyarakat, yang berupa potensi fisik dan geografi seperti alam. Selanjutnya,yang dimaksud potensi wisata adalah segala hal dan keadaan baik nyata dan dapat diraba maupun yang tidak teraba, yang digarap, diatur, dan disediakan sedemikian rupa sehingga dapat bermanfaat atau dimanfaatkan atau diwujudkan sebagai kemampuan; faktor dan unsur yang diperlukan atau menentukan bagi usaha dan pengembangan kepariwisataan, baik itu berupa suasana, kejadian, benda maupun layanan atau jasa-jasa. Suatu kawasan wisata yang baik dan berhasil bila secara optimal didasarkan pada 4 (empat) aspek meliputi: (1) mempertahankan kelestarian lingkungannya, (2) meningkatkan kesejahteraan masyarakat di kawasan tersebut, (3) menjamin kepuasan pengunjung, dan (4) meningkatkan keterpaduan dan unit pembangunan masyarakat di sekitar kawasan dan zone pengembangannya (Gunn, 1994).

Desa wisata adalah suatu wilayah perdesaan yang menawarkan keseluruhan suasana yang mencerminkan keaslian perdesaan baik dari segi kehidupan sosialekonomi, sosial budaya, adat istiadat keseharian, maupun arsitektur bangunan, dan struktur tata ruang desa yang khas. Desa wisata mengarah pada suatu bentuk kawasan permukiman yang terdapat pada daerah perdesaan baik secara sengaja ataupun tidak, telah menjadi sebuah kawasan yang menjadi tujuan kunjungan wistawan karena memiliki daya tarik atau obyek wisata dan di desa ini wisatawan dapat melakukan kegiatan menginap. Muhamad (2011) dalam salah satu bagian disertasinya menyampaikan Desa Wisata Sambi yang mempunyai potensi berupa kegiatan kesenian, karawitan, uyonuyon, dan wayang kulit. Desa ini mempunyai panorama yang indah yang dilatarbelakangi oleh Gunungapi Merapi.

Nuryanti (1993) berpendapat bahwa desa wisata merupakan suatu bentuk integrasi antara atraksi, akomodasi, dan fasilitas pendukung yang disajikan dalam suatu struktur kehidupan masyarakat yang menyatu dengan tatacara dan tradisi yang berlaku. Selain itu terdapat dua konsep yang utama dalam komponen desa wisata adalah (1) akomodasi, yaitu sebagian dari tempat tinggal para penduduk setempat dan atau unit-unit yang berkembang atas konsep tempat tinggal penduduk; (2) atraksi, yaitu seluruh kehidupan keseharian penduduk setempat beserta setting fisik lokasi desa yang memungkinkan wisatawan berintegrasi sebagai partisipasi aktif.

Pengembangan desa wisata sebagai obyek wisata perlu dipahami sejak awal bahwa masyarakat setempat bukan sebagai obyek pasif, tetapi justru sebagai subyek aktif. Sebuah lingkungan perdesaan dapat dipandang sebagai obyek sekaligus sebagai subyek wisata. Sebagai obyek desa tersebut merupakan tujuan kegiatan pariwisata, sedangkan sebagai subyek adalah sebagai penyelenggara, apa yang dihasilkan oleh desa akan dinikmati oleh masyarakatnya secara langsung dan peran aktif masyarakat sangat menentukan kelangsungannya. Pada pelaksanaan pariwisata berbasis komunitas khususnya bagi pengembangan desa wisata, masalah yang harus dipertimbangkan adalah partisipasi, pengambilan keputusan, pembangunan kapasitas masyarakat, dan akses ke pasar wisata.

Pengembangan Desa Wisata perlu diperhatikan aspek lingkungan hidup dan bencana alam, lebih-lebih Desa Wisata Sambi terletak di Lereng Gunungapi Merapi yang rawan bencana alam. Muta'ali (2013) telah meneliti desa-desa di Kawasan 
Bencana Merapi mengalami bencana dan selanjutnya melakukan pemulihan.Artinya bahwa di dalam pengembangan Desa Wisata Sambi risiko bencana Merapi perlu dipertimbangkan.

Hal penting lainnya dalam upaya pengembangan desa wisata yang berkelanjutan adalah pelibatan atau partisipasi masyarakat setempat, pengembangan mutu produk wisata pedesaan, dan pembinaan kelompok pengusaha setempat.

Penelitian ini dilaksanakan di Desa Wisata Sambi yang terletak di Kecamatan Pakem, Kabupaten Sleman, dengan pertimbangan sebagai berikut: (1) Desa wisata ini telah banyak diminati dan dikunjungi wisatawan baik lokal maupun mancanegara. (2) Walaupun daerah ini sebagian besar tidak terkena langsung bencana erupsi Gunungapi Merapi 2010, tetapi terkena dampak dari erupsi Gunungapi Merapi, jadi ada ancaman risiko bencana dari gunungapi tersebut. (3) Daerah ini mempunyai data sekunder yang lebih lengkap dan sudah sejak awal diteliti.

Desa Sambi yang berada di Jalan Kaliurang Km 19 memiliki aksesibilitas baik, mudah dijangkau dan terhubung dengan daerah-daerah lain di sekitarnya oleh jalur transportasi jalan raya. Wilayah Desa Sambi secara geografis berada di koordinat $07^{\circ} 38^{\prime} 45,44^{\prime \prime}$ LS- $07^{\circ} 39^{\prime} 4,96^{\prime \prime}$ LS dan $110^{\circ} 25^{\prime} 30,5^{\prime \prime} \mathrm{BT}-110^{\circ} 25^{\prime} 43,67^{\prime \prime}$ BT (Gambar 1).

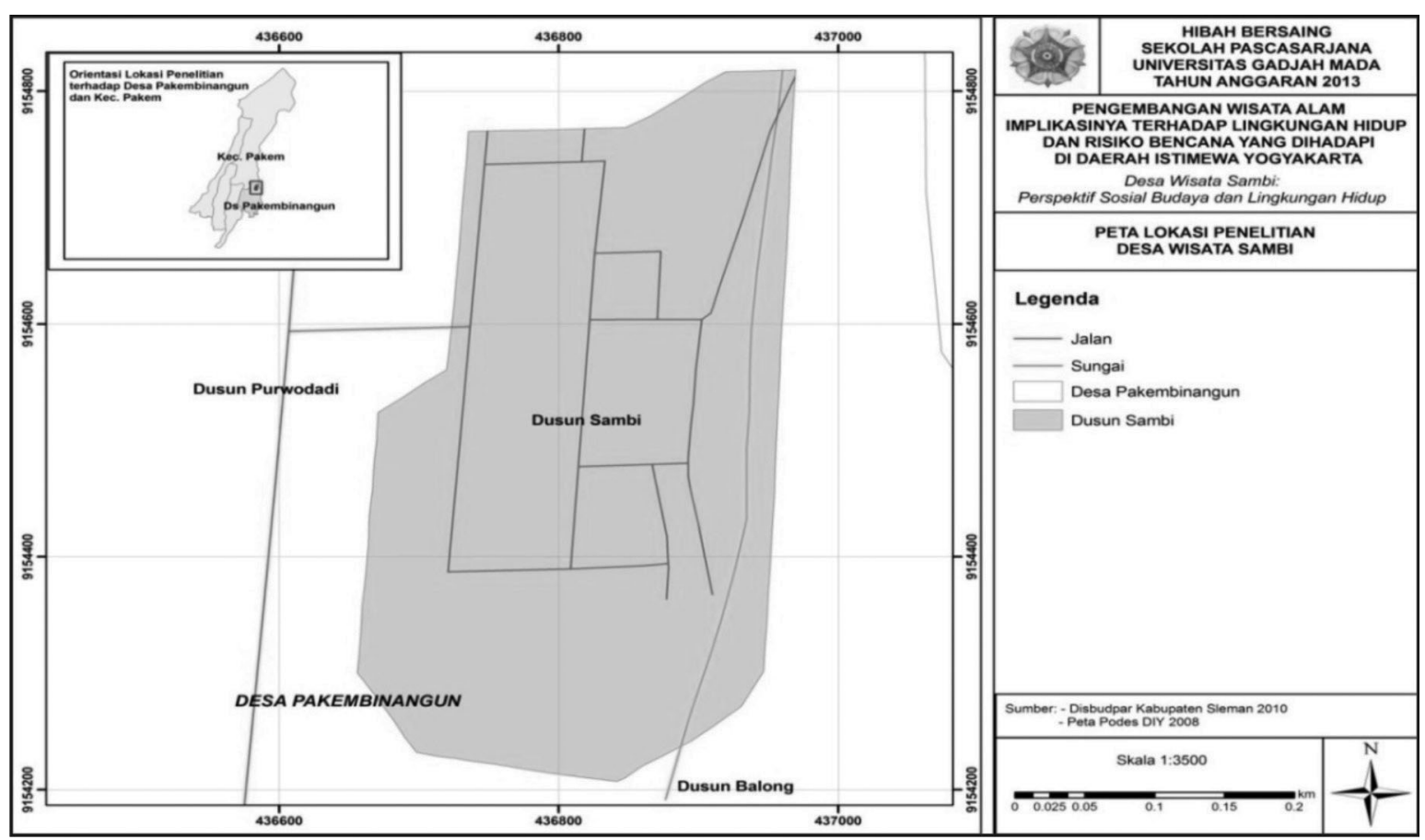

Gambar 1. Lokasi Penelitian

Bahan dan alat kerja yang dibutuhkan dalam penelitian ini sebagai berikut: Pertama, Peta RBI skala 1:50.000 Kabupaten Sleman, Peta Fisiografi skala 1:100.000 Kabupaten Sleman, Peta Geomorfologi skala 1:100.000 Kabupaten Sleman, Peta Geologi skala 1;100.000 Kabupaten Sleman, Peta Potensi Wisata skala 1:100.000 Kabupaten Sleman. Kedua, GPS dan Citra satelit, seperangkat instrument untuk sampling air $(\mathrm{pH}$ meter, EC meter), botol sampel air dan reagent.
Ketiga, Kuesioner untuk wawancara dengan penduduk maupun tokoh masyarakat setempat. Keempat, Kamera dan recorder untuk mendokumentasikan hasil wawancara.

Pada penentuan sampel yang digunakan dalam analisis ini meliputi komponen lingkungan, berupa komponen fisik, biotik, dan sosial-ekonomi-budaya. Sampel komponen lingkungan fisik dan biotik diambil di sekitar obyek wisata dimana kegiatan pariwisata dilakukan. Sampel yang terkait dengan 
komponen sosial ekonomi diambil dari anggota masyarakat setempat serta wisatawan yang berkunjung di Desa Wisata Sambi. Responden ditentukan dengan teknik purposive sampling, dengan pertimbangan bahwa sampel yang diambil telah diketahui sifat-sifatnya yang sesuai dengan permasalahan dan tujuan penelitian. Responden dipilih secara random sejumlah 27 responden dan wisatawan yang berkunjung sejumlah 29 orang.

Pada proses pengumpulan data dilakukan sebagai berikut: (1) Observasi langsung di lapangan tentang sumberdaya obyek wisata, aktivitas wisatawan dan atau perilaku masyarakat dalam menjaga kelestarian lingkungan; (2) Observasi kondisi lingkungan yang memungkinkan terjadinya risiko bencana alam (lereng curam, jarak terhadap puncak Gunung Merapi), kondisi sanitasi (limbah dan sampah); (3) Kuesioner, berisi pertanyaan yang terstruktur dengan jenis pertanyaan yang bersifat terbuka dan tertutup maupun gabungan keduanya; dan (4) Wawancara terstruktur dengan responden menggunakan kuesioner sebagai panduannya. Selain itu, dilakukan juga wawancara medalam, (Depth Interview) terhadap tokoh masyarakat dan pejabat daerah untuk mengetahui kebijakan dan kegiatan yang telah dilakukan secara kelembagaan.

Pengolahan dan analisis data dilakukan sebagai berikut: (1) Reduksi data,proses pemilahan, penyederhanaan dan transformasi data kasar; (2) Tabulasi hasil observasi dan pengukuran komponen lingkungan fisik dan biotis di lapangan; (3) Tabulasi data sosial: pemberian kode pada jawaban yang diberikan responden; (4) Mengelompokkan informasi yang sama dari jawaban responden untuk membuat simpulan tentang peran serta masyarakat dalam mengelola obyek wisata; dan (5) Analisis deskriptif untuk mengetahui partisipasi masyarakat dalam mengantisipasi dampak lingkungan dan risiko bencana.

\section{PEMBAHASAN}

\section{Gambaran Umum Desa Wisata Sambi}

Secara Geografis wilayah ini berada di Lereng Merapi sisi selatan, yang berbatasan dengan Kali Kuning dan dusun Bedoyo di sebelah timur. Dusun Pentingsari di sebelah utara, sebelah selatan dengan Dusun Balong, dan sebelah barat dengan Dusun Purwodadi. Secara Administratif Pedukuhan Sambi terletak di Desa Pakembinangun, Kecamatan Pakem, Kabupaten Sleman, Daerah Istimewa Yogyakarta. Padukuhan Sambi terletak di Jalan Kaliurang Km 19,5 Sleman Yogyakarta. Jarak ke ibukota kecamatan terdekat 3,5 km (Gambar 1).

Desa Wisata Sambi memiliki potensi wisata yang menarik untuk dikunjungi oleh wisatawan. Desa wisata ini, memiliki panorama alam yang sangat indah untuk dinikmati sehingga dapat memberikan kesegaran dan ketentraman hati, panorama alam pesawahan, dan pepohonan yang rindang serta kejernihan airnya juga rumahrumah adat seperti joglo, limasan, dan simon, dengan halaman yang luas, dapat dipakai media bermain sambil menikmati sejuknya udara serta suasana desa alami.

Desa Wisata Sambi merupakan satu dari sebelas desa wisata mandiri di Kabupaten Sleman. Desa Sambi mempunyai 'commercial branding' dengan menyebutnya "desa alami asli Jogja". Desa Sambi dikembangkan sebagai Desa Wisata sejak tahun 2001. Pengembangan pariwisata di Desa Wisata Sambi dilakukan oleh pengelola dengan cara mengajak masyarakat berpartisipasi secara aktif dan melibatkan seluruh lapisan masyarakat dalam setiap kegiatan pengembangan yang dicanangkan bersama antara pengelola dan masyarakat. Wujud nyata pemberdayaan masyarakat tersebut dilaksanakan melalui penerimaan dan pemanfaatan dana stimulan dari pemerintah pusat melalui PNPM Mandiri Pariwisata, yang sudah diterima selama tiga tahun berturut-turut, yaitu 2009, 2010, dan 2011. Realisasi pemanfaatan bantuan pemerintah tersebut, pengelola Desa Wisata Sambi bersama-sama dengan masyarakat telah (1) mengembangkan kegiatan masyarakat seperti membatik, pemanduan wisata, kuliner, dan membangun fasilitas outbound activity; (2) melaksanakan berbagai macam kegiatan 
adat; (3) merencanakan event pariwisata; (4) melestarikan budaya: melalui pagelaran wayang kulit; (5) meningkatkan pelayanan prima (service with heart); (6) merawat lingkungan hidup (dengan menanam pohon buah naga di sepanjang jalan desa); (7) mengusahakan pemerataan manfaat bagi masyarakat; dan (8) menjamin pengembalian keuntungan kepada masyarakat.

Luas Padukuhan Sambi lebih kurang 31,1 hektar dengan penggunaan lahan sebagaimana terlihat dalam Tabel 1.

Tabel 1. Penggunaan Lahan di Desa Wisata Sambi dan Luasnya

\begin{tabular}{l|l|l}
\hline No & \multicolumn{1}{|c|}{ Penggunaan Lahan } & \multicolumn{1}{c}{ Luas (ha) } \\
\hline 1. & Tanah Sawah Pertanian & 20 \\
\hline 2. & $\begin{array}{l}\text { Tanah Ladang dan } \\
\text { Permukiman }\end{array}$ & 6,9 \\
\hline 3. & $\begin{array}{l}\text { Tanah Fasilitas Umum/ } \\
\text { Kas Desa }\end{array}$ & 4,2 \\
\hline & Total & 31,1 \\
\hline
\end{tabular}

Sumber: Daftar Isian Data Dasar Profil Padukuhan Tahun 2013

\section{Kependudukan}

Di Pedukuhan Sambi tinggal 84 kepala keluarga. Jumlah total penduduk 281 jiwa, terdiri atas 134 laki-laki dan 147 perempuan. Mata pencaharian penduduk sangat beragam, antara lain buruh tani (8 orang), petani (17 orang), pedagang/wiraswasta (4 orang), PNS (18 orang), TNI/Polri (2 orang), montir (5 orang), sopir (2 orang), karyawan swasta (7 orang), tukang kayu (1 orang), dan tukang batu (2 orang). Mayoritas penduduk beragama Islam dengan jumlah 214 orang dan 17 orang beragama Katholik. Mata pencaharian penduduk desa wisata Sambi dapat dilihat dari Tabel2.

Tabel 2. Mata Penceharian Penduduk Desa Wisata Sambi

\begin{tabular}{l|l|l}
\hline No. & Jenis Mata Pencaharian & Jumlah \\
\hline 1. & Petani & 17 \\
\hline 2. & BuruhTani & 8 \\
\hline 3. & $\begin{array}{l}\text { Pedagang/wiraswasta/ } \\
\text { pengusaha }\end{array}$ & 4 \\
\hline 4. & TNI/POLRI & 2 \\
\hline 4. & Pegawainegerisipil & 18 \\
\hline 5. & Montir & 5 \\
\hline 6. & Supir & 2 \\
\hline 8. & KaryawanSwasta & 7 \\
\hline 9. & Tukangkayu & 1 \\
\hline 10. & TukangBatu & 2 \\
\hline
\end{tabular}

Sumber : Profil Pedukuhan, tahun 2013

Dari aspek kesehatan masyarakat, secara umum berkaitan dengan pemenuhan air bersih, 51 rumah tangga warga memiliki sumur gali sendiri. Pada perilaku hidup sehat terdapat 41 rumah tangga yang memiliki WC. Kebiasaan makan masyarakat 3 kali sehari.

\section{Potensi Wisata}

Beberapa potensi wisata yang ada di Desa Wisata Sambi antara lain beserta deskripsi singkatnya ditunjukkan dalam Tabel 3.

Tabel 3. Potensi Obyek Wisata di Desa Wisata Sambi

\begin{tabular}{l|l|l}
\hline No. & Obyek/Atraksi & \multicolumn{1}{c}{ Deskripsi Singkat } \\
\hline 1 & Panorama desa & $\begin{array}{l}\text { panorama desa yang sejuk, asri dan nyaman menjadi daya tarik } \\
\text { tersendiri bagi Desa Wisata Sambi. Wisatawan dapat berjalan menyusuri } \\
\text { desa (tracking) dengan dipandu oleh pemandu setempat. Tracking dapat } \\
\text { dilakukan sesuai permintaan wisatawan. }\end{array}$ \\
\hline 2 & Pertanian; & $\begin{array}{l}\text { lahan pertanian yang membentang di desa wisata Sambi merupakan } \\
\text { objek yang menarik. Wisatawan dapat mempraktekkan secara langsung } \\
\text { kegiatan-kegiatan pertanian seperti menanam padi, membajak sawah } \\
\text { dan belajar budidaya jamur. }\end{array}$ \\
\hline 3 & Peternakan & $\begin{array}{l}\text { Di Desa Sambi terdapat peternakan sapi perah. Wisatawan dapat } \\
\text { mempraktekan cara memerah susu sapi secara tradisional. Wisatawan } \\
\text { juga dapat belajar membudidayakan sapi perah. Wisatawan juga dapat } \\
\text { menangkap ikan tanpa bantuan alat di sawah. }\end{array}$ \\
\hline
\end{tabular}




\begin{tabular}{l|l|l}
\hline No. & Obyek/Atraksi & \multicolumn{1}{c}{ Deskripsi Singkat } \\
\hline 4 & Outbond & $\begin{array}{l}\text { Outbond di Desa Wisata Sambi dikhususkan di Ledok Sambi yang dekat } \\
\text { dengan lokasi Kali Kuning. Fasilitas yang terdapat di Ledok Sambi ini } \\
\text { antara lain arena outbond dengan fasilitas flying fox, meniti tali dan lain- } \\
\text { lain. }\end{array}$ \\
\hline 5 & Kesenian & $\begin{array}{l}\text { Desa wisata Sambi memiliki berbagai macam kesenian rakyat, antara } \\
\text { lain wayang kulit, karawitan Jawa dan uyon-uyon. Selain melihat } \\
\text { pertunjukan kesenian tersebut, wisatawan dapat mempelajari kesenian } \\
\text { tersebut. Pelatihan kesenian dilakukan dalam kelompok-kelompok. }\end{array}$ \\
\hline 6 & Kebudayaan & $\begin{array}{l}\text { kebudayaan yang terdapat di Desa Wisata Sambi antara lain kenduri, } \\
\text { sadranan, ruwahan dan lain-lain. Sadranan dilaksanakan pada setiap } \\
\text { tanggal 21 Sya'ban. Wisatawan dapat ikut serta dalam acara tersebut. }\end{array}$ \\
\hline 7 & $\begin{array}{l}\text { Rumah Joglo \& } \\
\text { Homestay }\end{array}$ & $\begin{array}{l}\text { Rumah Joglo yang terdapat di dusun Sambi dibangun pada tahun } \\
\text { 1952 dan sampai sekarang belum pernah mengalami pemugaran } \\
\text { atau renovasi. Wisatawan dapat menginap di homestay rumah-rumah } \\
\text { penduduk sekitar sehingga dapat berinteraksi langsung dengan } \\
\text { masyarakat. }\end{array}$ \\
\hline
\end{tabular}

Sarana pendukung parwisata di Desa Wisata Sambi antara lain berupaHomestay, Masjid, Resort, Sanggar seni, dan tari tempat bermain anak-anak serta outbond yang menempati di bantaran Sungai Kuning dan daerah sekitarnya.

Desa Wisata Sambi mempunyai potensi wisata yang cukup menarik, terlihat data kunjungnan wisatawan ke desa tersebut yang mengalami peningkatan, walaupun pada tahun 2010 terjadi erupsi Gunungapi Merapi yang besar. Akan tetapi, kunjungan wisatawan mancanegara terus mengalami penurunan (Tabel 4).

Tabel 4. Data Jumlah Kunjungan Wisata di Desa Wisata Sambi tahun 2002-2011

\begin{tabular}{l|l|l|l}
\hline No. & Tahun & $\begin{array}{c}\text { Wisatawan } \\
\text { Domestik (org) }\end{array}$ & $\begin{array}{c}\text { Wisatawan } \\
\text { Mancanegara (org) }\end{array}$ \\
\hline 1 & 2002 & 250 & 150 \\
\hline 2 & 2003 & 200 & 110 \\
\hline 3 & 2004 & 1187 & - \\
\hline 4 & 2005 & 1629 & 17 \\
\hline 5 & 2006 & 1138 & 4 \\
\hline 6 & 2007 & 3070 & - \\
\hline 7 & 2008 & 4187 & - \\
\hline 8 & 2009 & - & - \\
\hline 9 & 2010 & 1036 & - \\
\hline 10 & 2011 & 3883 & - \\
\hline
\end{tabular}

Sumber :Dinas Pariwisata Kab. Sleman

\section{Dampak Lingkungan Pengembangan dan Risiko Bencana}

Padaartikel ini telah digali informasi melalui wawancara dengan warga di wilayah Desa Wisata Sambi dan wisatawan sebagai responden. Adapun sampel yang diambil sebanyak 27 orang responden warga dan 29 orang wisatawan yang berkunjung pada bulan Agustus - September 2013.

\section{Aspek Budaya}

Di saat pengamatan di Desa Wisata Sambi serta wawancara dengan warga, secara umum diketahui bahwa budaya masyarakat setempat relatif masih terjaga, tetapiada beberapa hal terkait dengan budaya setempat yang mulai luntur dan dikuatirkan pada suatu saat akan punah. Berikut adalah deskripsi temuan aspek budaya Desa Wisata Sambi berdasarkan pengamatan dan wawancara dengan warga.

\section{Budaya Bertani}

Pertanian adalah bagian dari sistem mata pencaharian hidup yang merupakan salah satu unsur kebudayaan universal. Menurut Koentjaraningrat (2002:207), unsur sistem mata pencaharian dapat diperinci ke dalam beberapa sub-unsur, seperti perburuan, peladangan, pertanian, peternakan, perdagangan, perkebunan, industri, 
kerajinan, industri pertambangan, industri jasa, dan industri manufaktur.

Di Desa Wisata Sambi bertani adalah salah satu unsur budaya yang relatif masih terjaga, mengingat sebagian besar pekerjaan utama warga adalah dari sektor pertanian. Penduduk umumnya berada di rumah antara pukul 12.00-14.00 saat istirahat siang serta setelah Maghrib (di atas pukul 18.00). Selebihnya, sebagian besar warga menghabiskan waktunya di lahan pertanian (sawah atau tegalan), baik milik sendiri maupun menggarap milik orang lain. Aktivitas bertani ini dilakukan oleh warga yang sudah tua, sedangkan warga yang masih muda umumnya bekerja di luar daerah bahkan di luar Jawa. Alasan banyak anak muda pergi keluar daerah untuk bekerja, seorang petani menyatakan bahwa sebagian pemuda Dukuh Sambi merasa gengsi untuk bekerja di sektor pertanian. Mereka memilih keluar daerah untuk bekerja daripada tetap berada di tanah kelahiran.Keengganan anak muda bekerja di sektor pertanian karena merasa gengsi tidak sepenuhnya benarsebab ada responden yang menyatakan bahwa bekerja di luar sektor pertanian dengan alasan yang realistis, yaitu pendapatan di luar sektor pertanian yang relatif lebih pasti dibanding dengan jika bekerja di sektor pertanian.

Pernyataan hampir serupa dikemukakan oleh responden lain bahwa bekerja di luar bidang pertanian, yaitu di Sambi Resort karena jarak dari rumah ke tempat kerja cukup dekat. Dengan gaji sebagai karyawan tetap sekitar Rp 1 juta perbulan, dia dapat menghemat pengeluaran. Mengingat saat ini aktivitas bertani hanya dilakukan oleh generasi tua dan sangat sedikit generasi muda yang berminat kerja di bidang pertanian, mungkin suatu saat nanti aktivitas bertani akan hilang dari Desa Wisata Sambi karena tidak ada regenerasi. Dengan kata lain, bertani sebagai mata pencaharianyang merupakan salah satu unsur universal kebudayaan lama-lama akan hilang. Hal ini tentu akan mengancam salah satu atraksi wisata yang ada di Desa Wisata Sambi, yaitu atraksi di bidang pertanian (misal menanam padi, mencangkul, membajak sawah, dan sebagainya).

\section{Gotong Royong}

Salah satu budaya setempat yang sekarang sudah mulai pudar adalah nilai gotong-royong di antara warga. Hal ini antara lain terungkap dari hasil wawancara, yang menyampaikan tentang lunturnya nilai gotong-royong ini. Setiap pekerjaan yang dilakukan mengharapkan imbalan. Untuk memperbaiki fasilitas umum yang digunakan bersama (misal jalan dan talut), tetap harus ada orang tertentu yang harus dibayar. Salah satu orang yang harus dibayar adalah orang yang memasang (tukang) batu. Akan tetapi, dari wawancara tidak dapat dipastikan apakah nilai gotong-royong di Desa Wisata Sambi yang mulai luntur disebabkan oleh pariwisata atau memang karena perkembangan zaman. Nilai gotongroyong yang mulai luntur merupakan sebuah fenomena umum yang terjadi di negeri ini. Dengan demikian, gotong-royong yang mulai luntur di Desa Wisata Sambi juga dapat dikatakan sebagai sebuah bagian dari fenomena yang sudah umum tersebut.

Nilai gotong-royong di Desa Wisata Sambi yang mulai luntur merupakan "bentuk tradisi yang mulai pudar" dan menjadi "slogan yang indah dikatakan,tetapi sulit untuk dikerjakan" disadari oleh warga.Akan tetapi, selama di antara warga tidak ada gesekan terkait dengan kegiatan pariwisata, hal itu sudah bagus.

\section{Kenduri dan Nyadran}

Sebagian warga Desa Wisata Sambi masih memegang teguh religi yang diwariskan oleh nenek moyangnya. Bentuk kepercayaan yang dipegang oleh sebagian warga Desa Wisata Sambi antara lain dapat dilihat dalam tradisi kenduri dan nyadran. Tradisi yang masih hidup dan dilestarikan di Desa Wisata Sambi terkait dengan religi antara lain adalah tradisi kenduri dan nyadran. Nyadran biasa dilakukan pada bulan Syura (Muharram), Sapar (Syafar), Maulid (Rabilulawwal), 
sampai Syawwal. Kenduri masih dilakukan oleh sebagian warga, tetapi dahulu dilakukan oleh semua warga. Dalam pelaksanaan kenduri, dijelaskan bahwa Kenduri Syura pada tanggal 10 Syura, Syaffar pada tanggal 15. Selain merti dusun (bersih dusun) kenduri tanggal 15 Syaffar ditujukan untuk mengirim doa bagi Ki Ageng Gribig, sedangkan kenduri pada bulan Maulid dilaksanakan tanggal 12 Rabiulawal. Kenduri Ruwah (Syaban) pada tanggal 21, kenduri Selikuran tanggal tanggal 21 bulan Puasa (Ramadhan), dan kenduri Bada pada tanggal 1 Sawal (Syawal).

Jika dicermati, masyarakat di Desa Wisata Sambi mayoritas masih meyakini dan menjaga hubungan dengan para leluhur. Hal ini terlihat dari tujuan dilaksanakan setiap kenduri yang ditujukan untuk leluhur atau tokoh tertentu sebagaimana diuraikan di atas.

Selain kenduri, tradisi lain yang masih dilakukan warga adalah nyadran. Nyadran atau sadranan pada masyarakat Jawa biasanya dilakukan menjelang puasa Ramadhan, yaitu pada bulan Ruwah (kalender Jawa) atau bulan Syakban (kalender Hijriyah). Adapun spirit nyadran adalah sebagai ungkapan rasa syukur atas segala nikmat yang telah dirasakan. Rasa syukur tersebut diwujudkan secara kolektif dengan mengunjungi makam leluhur.

Uraian di atas secara jelas menggambarkan bahwa tradisi Nyadran masih dilaksanakan oleh warga Padukuhan Sambi yang dilaksanakan oleh 90 persen warga. Hal ini mengisyaratkan bahwa ada sebagian warga yang sudah tidak lagi melaksanakan tradisi Nyadran.

\section{Wiwit}

Untuk mengembangkan Desa Wisata Sambi, perlu ada atraksi unik yang dapat menjadi daya tarik bagi wisatawan sehingga mereka memutuskan untuk berkunjung ke Desa Wisata Sambi. Jika memungkinkan, bukan hanya wisatawan lokal, melainkan juga wisatawan mancanegara. Salah satu atraksi budaya yang sebenarnya dapat mendatangkan wisatawan adalah tradisi wiwit atau ritual yang dilakukan sebelum memanen padi. Sayang, tradisi ini sudah banyak ditinggalkan oleh warga Padukuhan Sambi. Hanya orang tertentu yang jumlahnya hanya beberapa yang masih melaksanakan tradisi wiwit. Jika dikemas secara menarik, wiwit adalah sebuah tradisi yang sangat potensial mendatangkan wisatawan.

Dari uraian di atas dapat disimpulkan bahwa budaya di Desa Wisata Sambi relatif masih terjaga, meskipun beberapa di antaranya terancam punah. Jika hal ini dibiarkan, tidak tertutup kemungkinan beberapa tradisi yang mulai ditinggalkan tersebut akan menuju kepada kepunahan. Oleh karena itu, perlu kepedulian semua pihak untuk ikut melestarikan budaya yang perlahan mulai ditinggalkan.

\section{Aspek Sosial}

Desa wisata sebenarnya adalah sebuah bentuk wisata minat khusus dikemas secara komprehensif sehingga para wisatawan dapat sepenuhnya berinteraksi dengan baik dengan lingkungan alam dan masyarakat sekitar serta budaya dan tradisi di dalamnya. Wisatawan dapat melihat dan merasakan secara langsung nilai-nilai kearifan lokal yang masih terasa dalam kehidupan masyarakat, seperti gotong royong, wiwit, sambatan/ rewang, kenduri/slametan, dolanan bocah, kesenian tradisional, ngluku atau membajak sawah dengan sapi, dan sebagainya. Tentu untuk menjadi pengunjung desa wisata membutuhkan keterlibatan partisipasi aktif masyarakat lokal dalam rangka menjamin keberlanjutan kegiatan wisata di desa wisata, sehingga, konsep desa wisata adalah untuk menawarkan harapan kehidupan yang lebih baik bagi masyarakat lokal dengan meningkatkan partisipasi aktif masyarakat dan mendorong keterlibatan masyarakat dalam setiap kegiatan yang ditujukan untuk pengunjung desa wisata.

Keterlibatan masyarakat sangat penting karena di desa wisata ini pola konsepinteraksi antara wisatawan dan masyarakat sebagai intinya. Terkait dengan organisasi pariwisata di Desa Wisata Sambi, ada tiga pemangku 
kepentingan di Desa Wisata Sambi, yaitu Ledok Sambi, Sambi Resort, dan Desa Wisata Sambi. Meskipun institusi ketiga pemangku kepentingan berbeda, pada kenyataannya ketiganya saling terkait. Hal ini dapat dilihat ketika pelanggan menginginkan kegiatan outbond, resor ini memiliki jalan lain untuk menuju Ledok Sambi Sambi atau Desa Wisata. Keterkaitan juga ditunjukkan oleh Ledok Sambi Sambi dan Desa Wisata. Ledok Sambi sebagai penyedia perjalanan pintu keluar dan desa wisata Sambi sebagai penyedia konsumsi. Dalam hubungan manajerial diagram antara ketiga stakeholder ditunjukkan pada Gambar 2.

\section{Padukuhan Sambi}

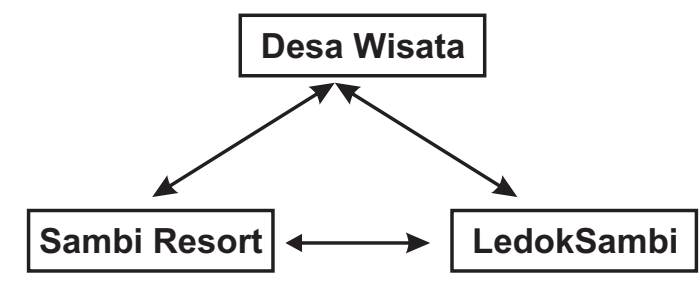

Gambar 2. Hubungan manajerial antara Desa Wisata Sambi Ketiga Stakeholder (Poedjiastuti, dkk., 2013)

Hubungan antara pemangku kepentingan publik, terlihat dalam pendirian catering untuk konsumsi wisatawan. Katering biasanya diberikan kepada kelompok katering milik warga Padukuhan Sambi. Ada 4 (empat) kelompok katering digunakan dalam rotasi untuk memberikan wisatawan untuk konsumsi.

Keberadaan Desa Wisata Sambi dengan tiga lembaga mengelola dampak positif pada masyarakat Padukuhan Sambi, antara lain meningkatnya pendapatan penduduk ekonomi, melalui rumah tinggal serta katering, dan sewa lahan, maka pembukaan lapangan kerja baru sehingga meminimalkan pengangguran.

Selain dampak positif, ada juga dampak negatif. Dampak negatif termasuk konflik laten antara manajerial. Konflik ini terjadi karena adanya konflik kepentingan antara para pemangku kepentingan. Pengelolaan sumber daya alam yang kurang diatur oleh konsensus, membuat aturan tunjangankelongaran, misalnya yang berkaitan dengan tanah komunitas sewa, konflik laten sering terjadi dalam proses, yaitu Desa Wisata Sambi, Sambi Resort dan Ledok Sambi karena finansial Ledok Sambi memiliki modal yang lebih dari Desa Wisata Sambi, maka pemilik lahan akan memilih disewa oleh Ledok Sambi karena mampu untuk membayar lebih dari Desa Wisata Sambi, sedangkan konflik laten yang terjadi di dewan desa wisata internal bukan merupakan konflik destruktif. Konflik ini dipicu karena kurangnya transparansi dalam anggaran pengelolaan Desa Wisata. Hal ini menyebabkan reformasi pengelolaan Desa Wisata Sambi tahun 2011, mengakibatkan penghentian aktivitas Desa Wisata Sambi selama hampir satu tahun.

\section{Aspek Lingkungan}

Berdasarkan hasil wawancara dengan masyarakat maupun pengunjung terkait dengan obyek wisata dan atraksi wisata di Desa Wisata Sambi, rata-rata masyarakat maupun pengunjung setuju kalau lokasi Desa Sambi sesuai untuk desa wisata dan dikembangkan menjadi wisata yang berkelanjutan karena selain alamnya yang indah, obyek wisata juga mendukung adanya pelestarian budaya/adat istiadat setempat dan unsur pendidikan. Dampak positif lain yang dapat ditingkatkan melalui aktivitas wisata adalah upaya pelestarian alam melalui aktivitas penggunaan dan pemanfaatan lahan sesuai peruntukan, pemanfaatan dan pemeliharaan sungai serta mata air, menumbuhkan sikap menjaga kebersihan dan kenyamanan lingkungan.

Pengembangan Desa Wisata Sambi, harus didukung ketersediaan sarana dan prasarana yang memadai. Di Desa Wisata Sambi, sudah tersedia sarana prasarana maupun fasilitas yang ada seperti homestay, arena bermain, akses jalan menuju ke lokasi Desa Sambi sudah tersedia dengan baik dan mudah dijangkau serta sarana prasarana lain.

Akan tetapi, tanggapan yang berbeda berasal dari pengunjung, terkait ketersediaan sarana prasarana tersebut, yang tercermin 
dari jawaban responden pengunjung antara lain mengenai aksesibilitas menuju ke lokasi Desa Sambi karena sarana transportasi umum agak susah. Perawatan arena bermain (outbond) yang ada saat ini kurang baik sehingga kondisinya sudah tidak terawat lagi. Ketersediaan tempat sampah masih kurang dan kebersihan lingkungan (khususnya kebersihan rumah) masih perlu ditingkatkan lagi.

Sebagai Desa Wisata, Sambi yang berada di lereng Gunungapi Merapi, mempunyai atraksi wisata yang ditawarkan adalah banyak memanfaatkan air sebagai wahana permainan maupun atraksi wisata lainnya. Oleh karena itu, perlu pula dikaji kondisi sumber air yang ada di Desa Sambi yang digunakan baik oleh masyarakat setempat maupun oleh pengunjung. Sumber air di Desa Sambi meliputi sumber air permukaan yaitu yang berasal dari Sungai Kuning, mata air, dan air tanah.

Sampel kualitas air Sungai Kuning diambil dua lokasi, satu sampel mata air dan dua sampel air sumur telah diteliti. Data kualitas air secara lengkap disajikan dalam Sudarmadji dkk. 2013. Kualitas air sungai menunjukkan beberapa parameter yang melebihi ambang batas baku mutu air Kelas II (berdasarkan PP. No. 82 th 2001), yaitu Posfat (masing-masing 1,220 mg/l dan 1,086 mgl) yang seharusnya dibawah $0,2 \mathrm{mg} / 1$. Kandungan pospat ini kemungkinan dapat berasal dari limbah cair rumah tangga dari mandi dan mencuci yang menggunakan sabun dan limbahnya dibuang ke sungai atau dapat pula berasal dari aktivitas pertanian (penggunaan pupuk). Selain itu kandungan fecal Coliform ( $>=2400 \mathrm{MPN} / 1000 \mathrm{ml}$ ) juga telah melebihi baku mutu (1000 MPN/100 $\mathrm{ml})$.

Kualitas air dari mata air menunjukkan beberapa parameter melebihi baku mutu air Kelas II (berdasarkan PP No. 82 th. 2001), yaitu oksigen terlarut $(7,39 \mathrm{mg} / \mathrm{l})$ yang seharusnya di bawah $4 \mathrm{mg} / \mathrm{l}$, pospat 1,435 $\mathrm{mg} / \mathrm{l}$ (baku mutu: 0,2 mg/l), serta timbal $(0,077 \mathrm{mg} / \mathrm{l}$, seharusnya tidak lebih dari 0,03 $\mathrm{mg} / \mathrm{l})$, seng $(0,243 \mathrm{mg} / \mathrm{l}$ seharusnya tidak lebih dari $0,05 \mathrm{mg} / \mathrm{l}$ ) serta fecal coliform (>>= $2400 \mathrm{MPN} / 100 \mathrm{ml}$, yang seharusnya tidak lebih dari $1000 \mathrm{MPN} / 100 \mathrm{ml}$ ).

Sampel air dari sumur warga, menunjukkan bahwa pada lokasi pertama, kekeruhannya $(7,99 \mathrm{mg} / \mathrm{l})$ sudah melebihi baku mutu air untuk keperluan air minum berdasarkan Permenkes No. 492/MENKES/ PER/IV/2010 yaitu sebesar $5 \mathrm{mg} / 1$. Kemudian secara bakteriologi (biologi), sampel air sumur pertama dan kedua keduanya tidak memenuhi persyaratan, karena telah melebihi baku mutu, yaitu terdapatnya E. Coli dan Coliform yang seharusnya tidak terdapat pada air yang digunakan untuk air minum.

\section{Risiko Bencana}

Desa Wisata Sambi merupakan daerah Padukuhan termasuk dalam Daerah Rawan Bencana I Merapi. Daerah rawan bencana merupakan daerah potensi ditumbuk lahar/ banjir dan tidak menutup kemungkinan merupakan perluasan awan panas dan aliran lava. Aliran lahar merupakan perpaduan antara aliran massa air melewati berbagai ukuran dan bahan yang berasal dari Gunung Merapi produk letusan gunung berapi pada tahun 2010 sekitar 130 juta $\mathrm{m}^{3}$ yang 30-40\% dalam bentuk awan panas masuk ke Sungai Gendol, sisanya masuk ke sungai lain. Awan panas dan sedimen di sungai merupakan potensi banjir lahar apabila terjadi hujan dengan intensitas tinggi. Meluapnya lahar merupakan ancaman bencana yang berasal dari badan sungai di daerah pemukiman, pertanian, dan infrastruktur. Ketika banjir lahar terjadi pada skala besar, warga terancam dan untuk mencegahnya dilakukan evakuasi (Bappenas dan BNPB, 2011).

Desa Wisata Sambi berbatasan dengan Sungai Kuning, yang merupakan salah satu sungai yang berhulu di Merapi. Pada letusan 2010, Desa Wisata Sambi terkena banjir lahar. Berdasarkan hasil wawancara dengan salah satu ketua dusun dan pengelola desa Wisata Sambi, sekitar 5 hektar sawah hilang akibat paparan banjir lahar Merapi. Lima hektar sawah kas desa hilang yang terletak di tepi 
Sungai Kuning. Pada saat letusan Merapi, beberapa arena outbond seperti berenang dan flying fox rusak oleh lahar dingin Merapi. Selain itu, sekitar 20 hektar sawah gagal panen akibat erupsi Merapi.

Para stakeholder Desa Wisata Sambi ada tiga, yaitu Ledhok Sambi, Sambi Resort, dan Desa Wisata Sambi. Ledhok Sambi menyewa tempat di tepi Sungai Kuning sebagai area permainan (outbond). Daerah yang rusak parah terkena banjir lahar Merapi harus ditutup beberapa waktu, mengakibatkan pendapatan masyarakat menurun, terutama bagi ibu-ibu yang tergabung dalam kelompok-kelompok yang memasak untuk wisatawan yang berkunjung Ledhok Sambi. Penurunan pendapatan juga dialami oleh orang-orang muda yang terlibat Desa Wisata Sambi sebagai fasilitator ketika ada wisatawan outbound datang.

Desa Wisata Sambi berjarak kurang dari 300 meter dari Sungai Kuning. BNPB menyatakan batas aman sungai yang berhulu pemukiman di ring 300 meter. Akan tetapi, batas dengan Sungai Kuning rumah sekitar 8 meter dan banjir lahar tidak mengancam rumah-rumah penduduk secara langsung. Banjir lahar dingin mengancam sawah yang terletak di sekitar Sungai Kuning. Ancaman lain adalah dariabu vulkanikGunung Merapi. Abu vulkanik dapat mengganggu kesehatan masyarakat, terutama mengganggu saluran pernafasan pada manusia. Di ladang, abu vulkanik dapat menyebabkan gagal panen karena lahan pertanian menjadi kering. Selain ancaman banjir lahar Merapi, bagian timur Desa Sambi berbatasan dengan tebing Sungai Kuning, membuat wilayah tersebut rawan longsor. Tanah longsor terjadi di wilayah tersebut dan merusak beberapa sawah di dalamnya.

\section{SIMPULAN}

Beberapa hal dapat disimpulkan dari penelitian ini sebagai berikut: pertama, Desa Wisata Sambi mempunyai potensi wisata alam yang baik berupa pemandangan alam serta budaya masyarakat yang masih terjaga.
Kedua, Masyarakat setempat mandapatkan banyak manfaat dari aspek ekonomi dari pengembangan Desa Wisata Alam, yang diperoleh dari berbagai macam kegiatan di Desa Wisata Sambi. Peluang usaha dan lapangan pekerjaan bertambah banyak dengan dikembangkannya Desa Wisata Sambi. Ketiga, Dampak positif berupa peningkatan pendapatan serta peluang berusaha timbul, tetapi di sisi lain juga timbul dampak negatif berupa penurunan kualitas lingkungan yang disebabkan oleh sampah. Lunturnya budaya lokal dapat juga terjadi di saat yang akan datang. Selain itu, risiko bencana dari aktivitas Merapi juga mungkin terjadi di Desa Wisata Sambi. Keempat, Dari sisi potensi pariwisata dan dan lingkungannya Desa Wisata Sambi mempunyai prospek pengembangan yang baik, tetapi dalam pengembangannya harus diperhatikan dampak lingkungan dan risiko bencana yang dihadapi.

\section{UCAPAN TERIMAKASIH}

Tulisan ini merupakan sebagian dari hasil penelitian hibah dosen tahun 2013 yang dibiayai oleh Sekolah Pascasarjana Universitas Gadjah Mada. Ucapan terimakasih Disampaikan pula kepada Tim peneliti, terutama Hermin Poedjiastoeti, S.Si, M.Si., dari Program Studi Ilmu Lingkungan, Febriana Muryanto, Eko Sugiarto dari Program Studi Kajian Pariwisata dan Martha Kurnia Dewi dari Program Studi Magister Manajemen Bencana, Sekolah Pascasarjana Universitas Gadjah Mada yang telah membantu dalam mengumpulkan data serta mengolah dan analisis data.

\section{DAFTAR PUSTAKA}

Gartner, W.C., 1976. Tourism Development, Principle, Processes and Policies. Van Nastrand, Reinhold, New York.

Gunn, C.A., 1994. Tourism Planning: Basic, Concept, Cases. Taylor and Francis Ltd, London.

Koentjaraningrat, 2002. Pengantar Ilmu Antropologi. Rineka Cipta, Jakarta. 
Muhamad, 2011. Kepariwisataan Berkelanjutan di Wilayah Yogyakarta bagian Utara Sebelum Erupsi 2010. Disertasi Doktor. Sekolah Pascasarjana UGM, Yogyakarta.

Muta'ali, L., Aditya, D. Dan Sofyan, M. 2013. Potential of the Recovery Level in Rural Areas, Merapi Disaster Prone. Proceeding. The MDGs to 2015 and Beyond: Success and Challanges in Developing Localized Strategies and Self Reliance. Gadjah Mada University; Okt. $30^{\text {th }}-31^{\text {th }}$.

Nuryanti, W., 1991. Dampak Sosial Budaya Pengembangan Pariwisata. Paper Seminat Pariwisata, Politeknik API Yogyakarta.

Pendit, N.S., 1999. Ilmu Pariwisata, Sebuah Pengantar. Pradnya Paramita, Jakarta.

Peraturan Pemerintah No. 82 tahun 2001 tentang Pengelolaan Kualitas Air dan Pengendalian Pencemaran Air.

Peraturan Menteri Kesehatan RI No. 492/ MENKES/PER/IV/2010 tentang Persyaratan Kualitas Air Minum.
Poedjiastuti, H. Febriana, M., Sugiarto, E., dan Martha, K.D. 2013. Sambi Tourism Village in Social, Cultural and Environmental Perspective. Proceeding. The MDGs to 2015 and Beyond: Success and Challanges in Developing Localized Strategies and Self Reliance. Gadjah Mada University; Okt. $30^{\text {th }}-31^{\text {th }}$.

Prasetyo, Y.E., 2010. Mengenal Tradisi Bangsa. Pusat Pengelolaan Lingkungan Hidup Regional Jawa. Yogyakarta.

Sudarmadji, Suyono dan Darmakusuma, 2012. Pengelolaan Sumberdaya Air Berbasis Kearifan Lokal Masyarakat Perdesaandi Daerah Fisiografi Gunungapidan Daerah Fisiografi Karst.Laporan Penelitian. Sekolah Pascasarjana UGM, Yogyakarta.

Sudarmadji, Haryono, E. Darmanto,D dan Widyastuti, M., 2013. Pengembangan Wisata Alam: Implikasinya terhadap Lingkungan Hidup dan Risiko bencana yang Dihadapi di Daerah Istimewa Yogyakarta. Laporan Penelitian. Sekolah Pascasarjana UGM, Yogyakarta. 